\title{
Physical and Combustion Characteristics of Briquettes Made from Water Hyacinth and Phytoplankton Scum as Binder
}

\author{
R. M. Davies ${ }^{1}$ and O. A. Davies ${ }^{2}$ \\ ${ }^{1}$ Department of Agricultural and Environmental Engineering, Niger Delta University, PMB 071, Yenagoa, Bayelsa State, Nigeria \\ ${ }^{2}$ Department of Fisheries and Aquatic Environment, Rivers State University of Science and Technology, PMB 5080, \\ Port Harcourt, Rivers State, Nigeria \\ Correspondence should be addressed to R. M. Davies; rotimidavies@yahoo.com
}

Received 29 March 2013; Accepted 20 August 2013

Academic Editor: Essam Eldin Khalil

Copyright (c) 2013 R. M. Davies and O. A. Davies. This is an open access article distributed under the Creative Commons Attribution License, which permits unrestricted use, distribution, and reproduction in any medium, provided the original work is properly cited.

\begin{abstract}
The study investigated the potential of water hyacinths and phytoplankton scum, an aquatic weed, as binder for production of fuel briquettes. It also evaluated some physical and combustion characteristics. The water hyacinths were manually harvested, cleaned, sun-dried, and milled to particle sizes distribution ranging from $<0.25$ to $4.75 \mathrm{~mm}$ using hammer mill. The water hyacinth grinds and binder (phytoplankton scum) at 10\% $\left(\mathrm{B}_{1}\right), 20 \%\left(\mathrm{~B}_{2}\right), 30 \%\left(\mathrm{~B}_{3}\right), 40 \%\left(\mathrm{~B}_{4}\right)$, and $50 \%\left(\mathrm{~B}_{5}\right)$ by weight of each feedstock were fed into a steel cylindrical die of dimension $14.3 \mathrm{~cm}$ height and $4.7 \mathrm{~cm}$ diameter and compressed by hydraulic press at pressure $20 \mathrm{MPa}$ with dwell time of 45 seconds. Data were analysed using analysis of variance and descriptive statistics. Initial bulk density of uncompressed mixture of water hyacinth and phytoplankton scum at different binder levels varied between $113.86 \pm 3.75\left(B_{1}\right)$ and $156.93 \pm 4.82 \mathrm{~kg} / \mathrm{m}^{3}\left(\mathrm{~B}_{5}\right)$. Compressed and relaxed densities of water hyacinth briquettes at different binder proportions showed significant difference $P<0.05$. Durability of the briquettes improved with increased binder proportion. Phytoplankton scum improved the mechanical handling characteristics of the briquettes. It could be concluded that production of water hyacinth briquettes is feasible, cheaper, and environmentally friendly and that they compete favourably with other agricultural products.
\end{abstract}

\section{Introduction}

The Niger Delta of Nigeria is characterized by extensive network of rivers and creeks which discharge their waters into the Atlantic Ocean. As a result, fishing is the major occupation of its inhabitants [1]. One of the most invasive and prolific aquatic weeds that devastate lakes, canals, rivers, and ponds in the Niger Delta is water hyacinth (Eichhornia crassipes). This aquatic weed blooms heavily in the Niger Delta due to favourable climatic condition [2]. In Niger Delta, the average weight or volume of fuelwood per day $\left(16.45 \mathrm{~kg}\right.$ or $\left.7.5 \mathrm{~m}^{3}\right)$ exceeds the Food and Agriculture Organization (FAO) average allowance $\left(0.46 \mathrm{~m}^{3}\right)$ [1]

The major source of energy in the rural community is fuelwood as other sources of energy are either not available or grossly inadequate. The demand for fuelwood is expected to rise to about $213.4 \times 10^{3}$ metric tonnes, while the supply will decrease to about $28.4 \times 10^{3}$ metric tonnes by the year 2030 [3]. Increasing pressure on forest resources for energy has led to what is called "other energy crisis of wood fuel" [4]. This has led to environmental degradation, deforestation, and misuse of soil forests and water resources. The uncontrolled level of cutting of wood for firewood and charcoal for combustion and for other domestic and industrial uses is now a serious problem in Nigeria. Total annual consumption of wood in Nigeria is estimated about $50-55$ million cubic meters of which $90 \%$ is firewood, while estimated shortfall of fuelwood in the northern part of the country is about $5-8$ million cubic meters [5]. The annual deforestation of the wood lands in the northern part of Nigeria runs to about 92,000 hectare a year. The fuelwood extraction rate in the country is estimated to be about 3.85 times the rate of regrowth or afforestation.

Water hyacinth is an aquatic weed that grows at an extremely rapid pace and its production is about 2 tonnes of 
biomass per acre and population doubles every 5-15 days [6]. The harvest frequency for aquatic plants tends to be in the order of days, whereas the frequency for trees and crops is in the order of years and months. The abundance, availability, low cost, and rapid growth of water hyacinths make them an ideal candidate for biofuel, particularly in the developing countries [7]. The objectives of this study are to investigate the potential of water hyacinths and phytoplankton, an aquatic weed, as organic binder for production of fuel briquettes and also determine some physical and combustion characteristics of the briquettes.

\section{Materials and Methods}

This study involved collection of samples in Port Harcourt, Niger Delta located between latitudes $402^{\prime \prime}$ and $602^{\prime \prime}$ north of the equator and longitudes $501^{\prime \prime}$ and $702^{\prime \prime}$ east of the Greenwich meridian [2]. Water hyacinth was harvested manually from the earthy fish ponds using drag net. Phytoplankton scum was harvested from concrete fish pond using scoop net and subsequently sun-dried. It was ground to fine particle size using plate mill and later sieved to particle size $0.075 \mathrm{~mm}$ with Tyler sieve. Water hyacinth sample was cleaned to be devoid of foreign matters (stone, dust, and plant materials) prior drying. It was sun-dried and finally milled to particle sizes distribution ranging from $<0.25$ to $4.75 \mathrm{~mm}$ using hammer mill. The particle size distribution was achieved by using particle size analysis equipment consisting of sieve shaker and Tyler sieves of various diameter or particles size openings. The percentages of binder used in the mixture were $10,20,30,40$, and $50 \%$ of residue weight. The agitating process was done in a mixer to enhance proper blending prior compaction. A steel cylindrical die of dimension $14.3 \mathrm{~cm}$ height and $4.7 \mathrm{~cm}$ diameter was used for this study. The die was freely filled with known amount of weight (charge) of each sample mixture and positioned in the hydraulic powered press machine for compression into briquettes.

The piston was actuated through hydraulic pump at the speed of $30 \mathrm{~mm} / \mathrm{min}$ of piston movement to compress the sample. Compacted pressure was $20 \mathrm{MPa}$. A known pressure was applied at a time to the material in the die and allowed to stay for 45 seconds (dwell time) before released and the briquette formed was extruded. A stopwatch was used for the purpose of timing. Prior to the release of applied pressure to the maximum depth of piston movement was measured for the purpose of calculating the volume displacement to enable the determination of compressive density of the briquette. Each briquette was replicated three times according to the level of process variables. The moisture content of the ground material before and after compaction was determined using ASABE [8] standard. Bulk density of the loose materials was determined according to ASABE [8] standard.

Compressed density was determined according to Bamgboye and Bolufawi [9] and Olorunnisola [10]. A steel cylindrical die of 14.3 by $4.7 \mathrm{~cm}$ was filled with $50 \mathrm{~g}$ of each sample mixture and was hydraulically compressed. A known pressure was applied through hydraulic at a time to the material in the die and allowed for 45 secs (dwell time) before released. The pressure was monitored through dial gauge installed on the machine. A stopwatch was used for timing. After compression, the height of briquette was measured and the volume was calculated. The briquette density was calculated by dividing the average mass of the briquette by its volume. The height and diameter of the briquette were consistently measured until they were stable. The stable height and diameter were used to calculate the new volume of the briquette since the charge was known initially.

Relaxed density and relaxation ratio were calculated as the ratio of compressed density to relaxed density according to Bamgboye and Bolufawi [9] and Olorunnisola [10]:

$$
\text { relaxation ratio }=\frac{\text { compressed density }}{\text { relaxed density }} \text {. }
$$

Percentage of water resistance capacity of dry briquette ( $10.3 \%$ wet basis) when immersed in cylindrical glass container containing distilled water at $29 \pm 2^{\circ} \mathrm{C}$ for 120 seconds was investigated. Relative change in weight of the briquette was measured. Percentage water gain was calculated using the following relationship:

$$
\% \text { water gained by briquette }=\frac{M_{2}-M_{1}}{M_{1}},
$$

where $M_{1}$ is the Initial weight of briquette before immersion and $M_{2}$ is the Final weight of briquette after immersion.

The equation becomes

$$
\begin{aligned}
& \text { water resistance capacity } \% \\
& \qquad=100 \%-\% \text { water absorbed. }
\end{aligned}
$$

See [11]. Briquettes shattering index (durability index) was determined according to ASTM D440-86 [12] of drop shatter developed for coal using the following equation:

$$
\begin{aligned}
& \text { shattering index } \\
& =\frac{\text { weight of briquettes retained on the screen after dropping }}{\text { weight of briquettes before dropping }}
\end{aligned}
$$

The static coefficient of friction of briquettes was investigated with respect to four test surfaces, namely, galvanised steel, rubber, plywood sheet, and aluminium sheet. A fiber box of $75 \mathrm{~mm}$ length, $50 \mathrm{~mm}$ width, and $30 \mathrm{~mm}$ height without base or lid was filled with sample and placed on an adjustable tilting plate, faced with test surface. The sample container was raised slightly $(10 \mathrm{~mm})$ so as not to touch the surface. The inclination of the test surface was increased gradually with a screw device until the box just started to slide down and the angle of tilt was measured from a graduated scale. For each replicate, the briquettes in the container were emptied and refilled with new briquettes. The static coefficient of friction was calculated as described by Mohsenin [13].

Briquette burning rate was determined according to the method used by Onuegbu et al. [14]. The insulator, Bunsen burner, tripod stand, and wire gauze were arranged on the balance and their weight was recorded. Briquette sample of 
known weight was placed on wire gauze and the burner ignited. This was positioned on top of a mass balance monitored to record instantaneous measurements of the mass every 10 seconds throughout the combustion process using a stopwatch, until the briquettes were completely burnt and constant weight was obtained. The weight loss at specific time was computed from the expression

$$
\text { burning rate }=\frac{\text { total weight of the burnt briquette }}{\text { total time taken }} .
$$

Calorific value of the sample was determined using Gallenkamp Ballistic Bomb Calorimeter according to ASTM E711-87 (2004).

Ignition time was determined according to Onuegbu et al., [14]. Each briquette was ignited by placing a Bunsen burner on a platform $4 \mathrm{~cm}$ directly beneath. Bunsen burner was used to ensure that the whole of the bottom surface of the briquette was ignited simultaneously after adjusting it to blue flame. Caution was taken to avoid flame spread in the transverse directions. The burner was left in until the briquette was well ignited and had entered into its steady state burn phase.

Thermal fuel efficiency of the energy was calculated according to Oladeji [15]

$$
\mathrm{TFE}=\frac{M_{w} C_{p}\left(T_{b}-T_{o}\right)+M_{c} L}{M_{f} E_{f}} \times 100 \% .
$$

The numerator gives the net heat supplied to the water while the denominator gives the net heat liberated by the fuel, where TFE is the thermal fuel efficiency of the energy, $M_{w}$ is the mass of water in the pot $(\mathrm{kg}), C_{p}$ is the specific heat of water $(\mathrm{kJ} / \mathrm{kgK}), T_{o}$ is the initial temperature of water $(\mathrm{K}), T_{b}$ is the boiling temperature of the water $(\mathrm{K}), M_{c}$ is the mass of water evaporated $(\mathrm{kg}), L$ is the latent heat of evaporation $(\mathrm{kg}), M_{f}$ is the mass of fuel burnt (kg), $E_{f}$ is the calorific value of the fuel $(\mathrm{kJ} / \mathrm{kg})$.

\section{Results and Discussion}

The obtained values for initial density of uncompressed mixture of water hyacinth at different binder levels varied from 113.86 to $156.93 \mathrm{~kg} / \mathrm{m}^{3}$ (Figure 1). The initial bulk density increase with increase in binder proportion. This signified a desirable development for the densification process. The obtained result is much lower than the corresponding values of uncompressed bulk densities of the residue materials as reported by Oladeji [16] were 95.33 and $98.00 \mathrm{~kg} / \mathrm{m}^{3}$ for corncob from white and yellow maize. The initial bulk density of uncompressed rice husk and corncob and water hyacinth of $138 \mathrm{~kg} / \mathrm{m}^{3}, 155 \mathrm{~kg} / \mathrm{m}^{3}$, and $40 \mathrm{~kg} / \mathrm{m}^{3}$ as reported $[17,18]$. These values are higher than the minimum value of $40 \mathrm{~kg} / \mathrm{m}^{3}$ recommended for wooden materials $[19,20]$. Importance of these results indicated the actualization of volume reduction of the raw material which provides a technological benefit. Density is an important parameter, which characterizes the briquetting process. If the density is higher, the energy/volume ratio is higher too. Hence, high density products are

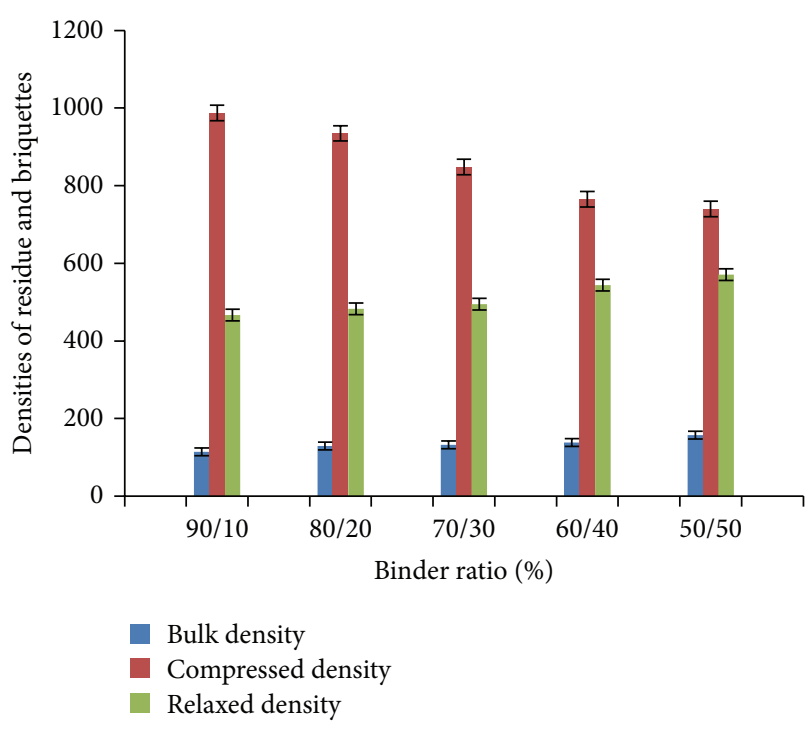

FIGURE 1: Densities of water hyacinth residue and briquettes.

desirable in terms of transportation, storage, and handling and are more cost effective than the natural state.

3.1. Compressed Density of Briquettes and Binder Proportions. Compressed densities of briquettes at the different binder proportions are presented in Figure 1. The recorded values showed an increase in binder (10-30\%) with decreased compressive density $\left(739.61\left(B_{5}\right)\right.$ to $\left.987.65 \mathrm{~kg} / \mathrm{m}^{3}\left(B_{1}\right)\right)$. The decline observed in compressed density with increased binder inclusion could be attributed to the binder occuping pores in-between the particles of water hyacinth. The recorded values of compressed density were higher than those of the initial bulk density (113.86 to $156.93 \mathrm{~kg} / \mathrm{m}^{3}$ ) of the uncompressed mixture of water hyacinth and binder. It is clearly shown that compressed density is inversely proportional to binder proportions. This trend was in disagreement with the values reported for production of fuel briquettes from waste paper and coconut husk admixture ranging from 8.1 to $11.2 \mathrm{~kg} / \mathrm{m}^{3}$ at different binder levels [10]. The effect of binder proportion on compressed density was studied and it was observed that the difference in binder type and blending ratio had significant effect on the compressed density of the briquettes $(P<0.05)$ [21]. These values are higher than the initial densities of the uncompressed mixture of corncob from white maize 151 to $235 \mathrm{~kg} / \mathrm{m}^{3}$ and 145 to $225 \mathrm{~kg} / \mathrm{m}^{3}$ for corncob from yellow maize. The values of compressed densities obtained are more than the minimum recommended value of $600 \mathrm{~kg} / \mathrm{m}^{3}$ and for efficient transportation and safe storage [20]. The equation representing the relationship between bulk density of mixture of water hyacinth and phytoplankton residue $\left(B_{d}\right)$, compressed density $\left(C_{d}\right)$, and relaxed density $\left(R_{d}\right)$ of water hyacinth briquettes with binder ratio $\left(B_{r}\right)$ and their coefficient of determination $\left(R^{2}\right)$ are presented as follows. The relationship existing between initial bulk density $\left(B_{d}\right)$ and binder ratio $\left(B_{r}\right)$ appears to be linear and a strongly positive correlation. Compressed and relaxed 
TABLE 1: Feedstock particle size distribution for production of briquettes.

\begin{tabular}{lc}
\hline Sieve size $(\mathrm{mm})$ & Percentage of material retained on the sieve $(\%)$ \\
\hline 4.75 & 1 \\
3.0 & 3 \\
2.0 & 4 \\
1.0 & 17 \\
0.5 & 32 \\
0.25 & 28 \\
$<0.25$ & 15 \\
\hline
\end{tabular}

densities of the briquettes also showed linear relationship with very high coefficient of determination:

$$
\begin{array}{cc}
B_{d}=4.7105 B_{r}+105.92, & R^{2}=0.9189, \\
C_{d}=33.28 B_{r}+1054.8, & R^{2}=0.9409, \\
R_{d}=13.495 B_{r}+430.84, & R^{2}=0.9764 .
\end{array}
$$

The interaction between relaxed density and binder levels varied from $466.97 \pm 7.91 \mathrm{~kg} / \mathrm{m}^{3}\left(B_{1}\right)$ to $571.24 \pm 10.37 \mathrm{~kg} / \mathrm{m}^{3}\left(B_{5}\right)$ (Figure 1). The relaxed density increased with the increasing binder proportion. It could be inferred that the optimum amount of binder required for densification was $50 \%\left(B_{5}\right)$. At this level of binder, the produced briquettes have the required strength to withstand handling, transportation, and storage. Conversely, the corresponding report revealed that the binder types and blending ratio had no significant influence $(P>$ 0.05 ) on compressed density [21]. The binder (phytoplankton scum) used competed favourably with more than 50 organic and inorganic binders that have been reported for densification. A similar trend was reported on the relationship between relaxed density and binder proportions [22, 23]. Those studies reported increased the relaxed density with the increase in binder proportion for the production of sawdust and palm oil sludge briquettes. Increase in relaxed density with increased binder proportion was equally observed for production of some briquettes from sawdust, rice husk, peanut shell, coconut fibre, and palm fibre [24] (Table 1).

The effect of binder on the compaction ratio ranged from $4.713\left(B_{1}\right)$ to $8.684\left(B_{1}\right)$ for all the five binder proportions utilized (Figure 2). This is an indication that the volume displacement is high. This is good for packaging, storage and transportation and above all, it is an indication of good quality briquettes. This showed that void spaces are expelled at higher binder ratio. There was more resistance to compression as the binder ratio increased.

The values of compaction ratio obtained in this study compare and compete favourably with other biomass residues. Compaction ratio of 3.80 for briquetting of rice husk was observed $[17,18]$. Compaction ratios of 3.5 and 4.2 were reported for densification of groundnut and melon shells, respectively [25]. Compaction ratio varied from 3.194 to 9.730 for briquettes from Guinea corn (Sorghum Bi-color) residue [9]. The compaction ratio of briquettes produced from white corncob increased with increasing binder ratio [16].

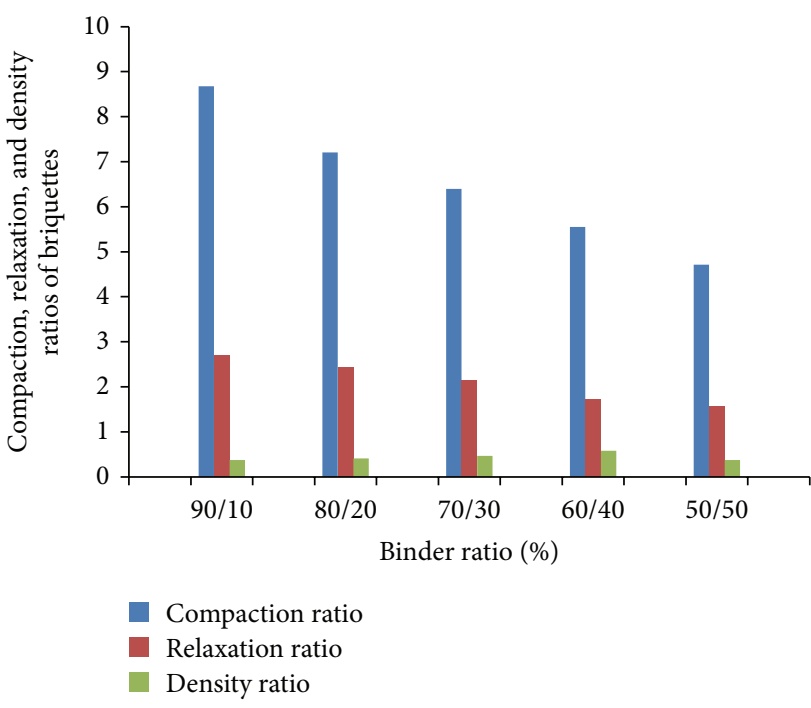

Figure 2: Effect of binder on compaction, relaxation, and density ratios of briquettes.

The relaxation of the briquettes varied from $1.569 \pm 0.12$ $\left(B_{1}\right)$ to $2.691 \pm 0.07\left(B_{5}\right)$ for the five studied binder levels (Figure 2). The difference in the relaxation ratio of briquette at the different binder proportions was significant $(P<0.001)$. The obtained range of relaxation ratio in this study is still within the reported range of 1.8 to 2.5 and 1.65 to 1.8 [10, 26]. Relaxation ratio values were 1.11 and 1.32 for briquettes produced from charcoal and Arabic gum, respectively, but briquettes made from charcoal and cassava starch had relaxation ratio values of 1.17 and 1.34 [21]. The obtained values of relaxation ratio signified that briquettes of low relaxation ratio exhibited low elastic property and more stability while briquettes of high relaxation ratio exhibited high tendency of elastic property and less stability. A similar observation was made for briquettes produced from hay material which had relaxation ratio of 1.68 to 1.8 [26]. The lower values ratio indicates a more stable briquette, while higher value indicates high tendency towards relaxation, that is, less stable briquette.

The density ratio of the briquettes ranged from $0.371 \pm$ $0.02\left(B_{1}\right)$ to $0.580 \pm 0.07\left(B_{5}\right)$ for the five studied binder levels (Figure 2). The obtained range of relaxation ratio in this study is within the reported range of 0.173 to 0.497 [9].

The result of water resistance property of the briquettes varied from $52 \pm 2.42 \%\left(B_{1}\right)$ to $97.1 \pm 3.39 \%\left(B_{5}\right)$ for the five studied binder levels (Figure 3). It was observed that the briquette produced from binder (50\%) had good hygroscopic properties as compared to the briquettes from the other four combinations. The briquette from $\mathrm{B}_{5}$ exhibits the least water absorption characteristic. This is an indication that hygroscopic property of briquettes at different binder proportions showed a decrease in water absorption capacity with increased quantity of utilized binder. The percentages of water resistance penetration of carbonized cashew shell, rice husk, and grass briquettes were investigated when immersed in water at $27^{\circ} \mathrm{C}$ for 30 seconds. It was observed that the briquetted fuel from carbonized cashew shell had low percentage 


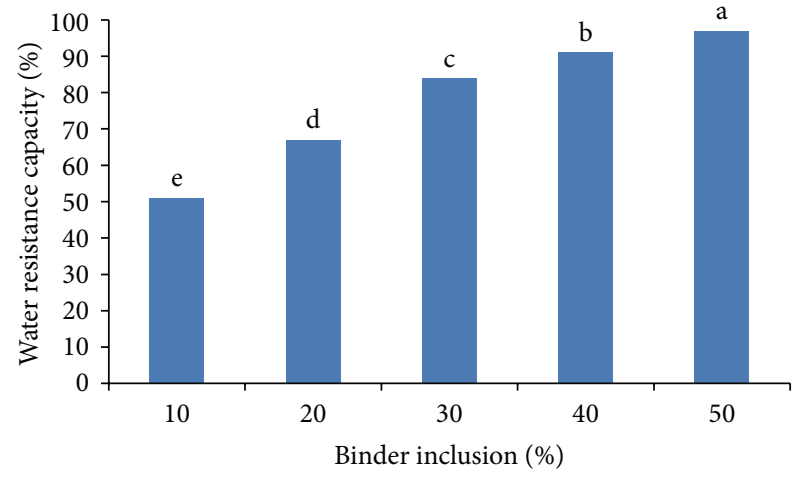

FIGURE 3: Effect of binder on water resistance of briquette. Means of the same letter are significantly different $(P<0.05)$.

of water resistance penetration of less than $10 \%$ as compared to the briquetted fuel from carbonized rice husk and grass that had percentage of water resistance penetration of about 35 and $45 \%$. The briquetted fuel from carbonized cashew shell required minimum energy for production and low water absorption properties [11].

The effect of binder proportion on the shattering index of the briquettes was conducted as shown in Table 2. The mean shattering index ranged between $0.59 \pm 0.01\left(B_{1}\right)$ and $0.98 \pm 0.03\left(B_{5}\right)$ and variation of the values was significant $(P<0.001)$. It could be inferred that the amounts of binder used have significant influence on the durability rating of the briquettes $(P<0.05)$. The mean values of shattering index for binders $B_{1}(0.59 \pm 0.01)$ and $B_{2}(0.74 \pm 0.03)$ were low and showed significant difference $(P<0.05)$; thus, they might not be suitable for briquettes production.

Meanwhile, the mean values of shattering index of $B_{4}$ $(0.91 \pm 0.01)$ and $B_{5}(0.98 \pm 0.01)$ fall within the acceptable range of DIN51731 [27] and Kaliyan and Morey [19] for production briquettes. This implies that $\mathrm{B}_{5}$ is the optimum binder level requirement to produce durable, reliable, and stable briquettes that stand mechanical handling and transportation, with economical feasibility and environmental friendliness. It discovered that increase in binder proportion and types of binder have a significant effect on the durability rating of the briquettes [21, 22].

The effect of types of binders and quantity on the durability of briquettes was reported [28]. It was observed that adding $10-25 \%$ (by weight) of molasses or sodium silicate or a mixture of $50 \%$ molasses and $50 \%$ sodium silicate with rice straw produced briquettes with $40-80 \%$ durability at a particle size of $0.15 \mathrm{~mm}$ and forming pressure of $29.4 \mathrm{MPa}$ [19]. It was also found that the higher the amount of binder inclusion, the higher the briquette durability rating. Addition (by weight) of any of the following six binders did not improve the alfalfa pellet durability over the control: $4 \%$ bentonite, 1.5\% Perma-Pel (lignosulfonate), $1.5 \%$ Lignosite $458,4 \%$ of neutralized liquid Lignosite, $4 \%$ of liquid molasses, and $40 \%$ of ground barley grain [19].

The interaction between crushing strength and binder levels varied from $104.00 \pm 3.86 \mathrm{~N}\left(\mathrm{~B}_{1}\right)$ to $263.50 \pm 5.76 \mathrm{~N} \mathrm{(B_{5 } )}$ (Table 2). The load required to rupture briquettes at different
TABLE 2: Mechanical handling characteristic of briquettes.

\begin{tabular}{lcc}
\hline Binder ratio & Shattering index & Crushing strength $(\mathrm{N})$ \\
\hline $90: 10$ & $0.59 \pm 0.01$ & $104.00 \pm 3.86$ \\
$80: 20$ & $0.74 \pm 0.03$ & $139.60 \pm 4.17$ \\
$70: 30$ & $0.89 \pm 0.04$ & $164.00 \pm 3.08$ \\
$60: 40$ & $0.91 \pm 0.02$ & $222.30 \pm 5.26$ \\
$50: 50$ & $0.98 \pm 0.03$ & $263.50 \pm 5.76$ \\
\hline
\end{tabular}

binder ratios was significantly different $(P<0.05)$. The crushing strength increased with increasing binder proportion. This is an indication that phytoplankton as binder has a good binding power that competed favourably with binders from other biomasses. It could be inferred that the optimum amount of binder required to produce high quality briquettes is $50 \%\left(B_{5}\right)$. At this level of binder, the produced briquettes have the required strength to withstand handling, transportation and storage.

The coefficient of static friction of the water hyacinth briquette ranged from $0.35\left(\mathrm{~B}_{5}\right)$ to $0.47\left(\mathrm{~B}_{1}\right)$ for galvanized steel as shown in Table 3. This is an indication that at higher binder ratio, the briquette becomes more pliable and smoother due to the glossy nature of phytoplankton. The briquettes on aluminium and plywood sheet had the lowest and highest values for static coefficient of friction at different binder ratio, respectively. The lowest static coefficient of friction was recorded for aluminium sheet, $0.31\left(B_{5}\right)$. The highest static coefficient of friction corresponds to plywood sheet, 0.56 $\left(B_{1}\right)$. The coefficient of static friction of water hyacinth briquette on plywood sheet at different binder ratios were statistically different $(P<0.05)$.

The obtained values of thermal fuel efficiency of water hyacinth briquettes are shown in Table 4 . The results showed that increased binder subsequently increasing the thermal fuel efficiency of briquettes from $19.67 \pm 0.23\left(B_{1}\right)$ to $31.73 \pm$ $0.93 \%\left(B_{5}\right)$. The result of analysis variance showed that there was a significant difference among the obtained values $(P<$ $0.05)$. Binder $\mathrm{B}_{4}$ could be regarded as the optimum binder level required to produce briquettes of acceptable thermal fuel efficiency and low smoke as compared to firewood briquettes. The consequent of selecting any other binder level higher than binder $\mathrm{B}_{4}$ amounted to energy and economic losses. In addition, it could be inferred that any increase in binder proportion beyond $\mathrm{B}_{4}$ has no significant influence on the fuel efficiency of the briquettes. However, briquettes with binder levels lower than $\mathrm{B}_{4}$ might not be acceptable.

The effect of binder on ignition time of the briquettes varied from $73.54 \pm 3.37 \mathrm{sec}\left(\mathrm{B}_{1}\right)$ to $123.42 \pm 3.47 \mathrm{sec}\left(\mathrm{B}_{5}\right)$ as shown in Table 4 . The obtained trend of the ignition time indicated that ignition time increased with increasing binder proportion. The recorded lowest ignition time (73.54 \pm $3.37 \mathrm{sec}$ ) recorded for $\mathrm{B}_{1}$ could be attributed to high porosity exhibited between inter- and intraparticles which enable easy percolation of oxygen and outflow of combustion briquettes due to low bonding force. The values were significantly different at all levels of binder $(P<0.05)$. Ignition time for $100 \%$ coal briquette sample took 286 sec to ignite [15]. 
TABle 3: Coefficient of static friction.

\begin{tabular}{lcccc}
\hline Binder ratio & Galvanised steel & Rubber & Plywood sheet & Aluminium sheet \\
\hline $90: 10$ & $0.47( \pm 0.02)$ & $0.48( \pm 0.03)$ & $0.56( \pm 0.02)$ & $0.43( \pm 0.01)$ \\
$80: 20$ & $0.46( \pm 0.01)$ & $0.44( \pm 0.02)$ & $0.51( \pm 0.03)$ & $0.37( \pm 0.01)$ \\
$70: 30$ & $0.41( \pm 0.05)$ & $0.44( \pm 0.03)$ & $0.49( \pm 0.01)$ & $0.38( \pm 0.03)$ \\
$60: 40$ & $0.37( \pm 0.03)$ & $0.38( \pm 0.01)$ & $0.45( \pm 0.04)$ & $0.33( \pm 0.05)$ \\
$50: 50$ & $0.35( \pm 0.04)$ & $0.34( \pm 0.02)$ & $0.43( \pm 0.03)$ & $0.31( \pm 0.03)$ \\
\hline
\end{tabular}

TABLE 4: Combustion characteristics of water hyacinth briquettes and binder proportions.

\begin{tabular}{lccccc}
\hline Combustion parameters & \multicolumn{4}{c}{ Binder ratio } & \\
& $10 \%$ & $20 \%$ & $30 \%$ & $40 \%$ & $30 \%$ \\
\hline Thermal fuel efficiency (\%) & $19.67 \pm 0.23 \mathrm{~d}$ & $21.82 \pm 0.35 \mathrm{c}$ & $23.67 \pm 0.21 \mathrm{~b}$ & $31.24 \pm 0.48 \mathrm{a}$ & $31.73 \pm 0.93 \mathrm{a}$ \\
Calorific value (Kcal/kg) & $3563 \pm 76.94 \mathrm{e}$ & $3791 \pm 83.15 \mathrm{~d}$ & $3864 \pm 41.03 \mathrm{c}$ & $4195 \pm 32.96 \mathrm{~b}$ & $4281 \pm 90.78 \mathrm{a}$ \\
Ignition time (min.) & $73.54 \pm 3.37 \mathrm{e}$ & $88.27 \pm 1.23 \mathrm{~d}$ & $93.54 \pm 3.82 \mathrm{c}$ & $114.37 \pm 4.12 \mathrm{~b}$ & $123.42 \pm 3.47 \mathrm{a}$ \\
Burning rate (g/min) & $2.25 \pm 0.01 \mathrm{a}$ & $2.01 \pm 0.03 \mathrm{~b}$ & $1.89 \pm 0.04 \mathrm{c}$ & $1.71 \pm 0.02 \mathrm{~d}$ & $1.63 \pm 0.02 \mathrm{e}$ \\
\hline
\end{tabular}

Means with same letter along the column are not significantly different $(P>0.05)$.

The effect of binder on the burning rate was studied. From Table 4, burning rate of water briquettes significantly varied between $1.63 \pm 0.02 \mathrm{~g}^{-1} \min \left(B_{5}\right)$ and $2.25 \pm 0.01 \mathrm{~g}^{-1} \min \left(B_{1}\right)$ $(P<0.05)$. The obtained burning rate values of the briquettes decreased with increasing binder proportion. The implication of this observation is that more fuel might be required for cooking with briquettes produced from $B_{1}$ than from $B_{5}$.

The calorific values of briquettes produced from mixture of water hyacinth and binder at different levels are presented in Table 4. The calorific values of the briquettes ranged between $3563 \pm 76.94 \mathrm{kcal} / \mathrm{kg}\left(\mathrm{B}_{1}\right)$ and $4281 \pm$ $90.38 \mathrm{kcal} / \mathrm{kg}\left(\mathrm{B}_{5}\right)$. This showed that phytoplankton scum as binder improved the calorific value of water hyacinth from $3190 \mathrm{kcal} / \mathrm{kg}$ (sample $100: 0$ ). The recorded values of calorific values were significant at the different binder levels $(P<$ 0.05). Adegoke [29] reported an improvement in calorific value of briquettes of palm kernel shell mixed with sawdust from $19.91 \mathrm{MJ} / \mathrm{kg}(4755.4 \mathrm{kcal} / \mathrm{kg}) \mathrm{MJ} / \mathrm{kg}$ to $20.54 \mathrm{MJ} /$ $\mathrm{kg}(4905.9 \mathrm{kcal} / \mathrm{kg})$. The calorific value of the briquettes is within the acceptable range for commercial briquette ( $>4179.8 \mathrm{kcal} / \mathrm{kg}$ ) DIN 51731 [27]. It was observed that briquettes produced from binder ratio $B_{1}$ to $B_{3}$ are not be suitable for the production of commercial briquettes.

\section{Conclusion}

The optimum binder level required to produce the briquettes with the highest durability strength is $50 \%$ binder ratio. The best shatter and durability indices showed that they have good shock and impact resistance and are good for handling and transportation. They also have good density ratio. Therefore, combination of water hyacinth and phytoplankton scum is very suitable for briquette production for domestic and industrial uses. The physical and mechanical handling characteristics of water hyacinth briquettes compete favourably with other biomass briquettes. Binder $\mathrm{B}_{4}$ could be regarded as the optimum binder level required to produce briquettes of acceptable thermal fuel efficiency and low smoke as compared to firewood briquettes. Water hyacinth only without binder might not satisfy the minimum calorific value. Utilization of phytoplankton scum, an aquatic weed, as organic binder exhibits a good binding characteristic.

\section{Conflict of Interests}

The authors declared that there is no conflict of interests.

\section{References}

[1] O. A. Osi, Survey of fish processing machinery in Bayelsa State [B.Sc. Thesis], Niger Delta University, Nigeria, 2008.

[2] C. C. Tawari, Effectiveness of agricultural agencies in fisheries management and production in the Niger Delta, Nigeria [Ph.D. thesis], Rivers State University of Science and Technology, Port Harcourt, Nigeria, 2006.

[3] A. O. Adegbulugbe, "Energy-environmental issites in Nigeria," International Journal of Global Energy Issues, vol. 6, no. 12, pp. 7-18, 1994.

[4] J.-F. K. Akinbami, "Renewable energy resources and technologies in Nigeria: present situation, future prospects and policy framework," Mitigation and Adaptation Strategies for Global Change, vol. 6, no. 2, pp. 155-181, 2001.

[5] Nigeria Environmental Action Team (NEST), "Nigeria Threatened Environment. A Natural Profile 'Atmosphere,' NEST, Ibadan, Nigeria.Pp. 116-117, 2001.

[6] M. A. Olal, M. N. Muchilwa, and P. L. Woomer, "Water Hyacinth, Utilizations and the use of waste material for Handicraft production in Kenya," in Micro and Small Enterprises and Natural Resource Use, D. L. M. Nightingale, Ed., pp. 119-127, MicroEnterprises Support Programme UNRP, Nairobi, Kenya, 2001.

[7] D. Sophie, "A fast-Growing Plant Becomes mod furniture," in Connecticut Cottage Gardens, Cuttoges and Gardens, Norwalk, Conn, USA, 2006.

[8] American Society of Agricultural and Biological Engineering (ASABE), "Cubes, pellet and crumbles definitions and methods for determining density, durability and moisture content," ASAE DEC96, St. Joseph, Mich, USA, 2003.

[9] A. Bamgboye and S. Bolufawi, "Physical characteristics of briquettes from Guinea corn (sorghum bi-color) residue," Agricultural Engineering International, article 1364, 2008. 
[10] A. O. Olorunnisola, "Production of fuel briquettes from waste paper and coconut husk admixtures," Agricultural Engineering International, vol. 1X, article EE 06 066, 2007.

[11] S. H. Sengar, A. G. Mohod1, Y. P. Khandetod, S. S. Patil, and A. D. Chendake, "Performance of briquetting machine for briquette fuel," International Journal of Energy Engineering, vol. 2, no. 1, pp. 28-34, 2012.

[12] American Society for Testing and Materials (ASTM. D440-86), "Standard test method of drop shatter test for coal," in Annual Book of ASTM Standards, vol. 05, pp. 188-191, West Conshohocken, Pa, USA, 1998.

[13] N. N. Mohsenin, Physical Properties of Plant and Animal Materials, Gordon and Breach Press, New York, NY, USA, 1986.

[14] T. U. Onuegbu, U. E. Ekpunobi, I. M. Ogbu, M. O. Ekeoma, and F. O. Obumselu, "Comparative studies of ignition time and water boiling test of coal and biomass briquettes blend," International Journal of Research \& Reviews in Applied Sciences, vol. 7, pp. 153-159, 2012.

[15] J. T. Oladeji, The effects of some processing parameters on physical and combustion characteristics of corncob briquettes [Ph.D. thesis], Department of Mechanical Engineering, Ladoke Akintola University of Technology, Ogbomoso, Nigeria, 2011.

[16] J. T. Oladeji, "A comparative study of effects of some processing parameters on densification characteristics of briquettes produced from two species of corncob," The Pacific Journal of Science and Technology, vol. 13, no. 1, pp. 182-192, 2012.

[17] J. T. Oladeji, "Pyrolytic conversion of sawdust and rice husk to medium grade fuel," in Proceedings of the Conference of the Nigerian Institute of Industrial Engineers (NIIE '10), pp. 81-86, Ibadan, Nigeria, April 2010.

[18] R. M. Davies and U. S. Mohammed, "Moisture-dependent engineering properties water hyacinth parts," Singapore Journal of Scientific Research, vol. 1, no. 3, pp. 253-263, 2011.

[19] N. Kaliyan and R. Morey, "Densification characteristics of corn stover and switchgrass," in Proceedings of the ASABE Annual International Meeting, paper 066174, St. Joseph, Mich, USA, 2006.

[20] S. Mani, L. G. Tabil, and S. Sokhansanj, "Specific energy requirement for compacting corn stover," Bioresource Technology, vol. 97, no. 12, pp. 1420-1426, 2006.

[21] O. A. Sotannde, A. O. Oluyege, and G. B. Abah, "Physical and combustion properties of charcoal briquettes from neem wood residues," International Agrophysics, vol. 24, no. 2, pp. 189-194, 2010.

[22] O. A. Ajayi and C. T. Lawal, "Hygroscopic and combustion characteristics of sawdust briquettes with palm oil sludge as binder," Journal of Agricultural Engineering and Technology, vol. 5, pp. 29-36, 1997.

[23] W. H. Engelleitner, "Binders: how they work and how to select one," Powder and Bulk Engineering, vol. 15, no. 2, pp. 31-37, 2001.

[24] O. C. Chin and K. M. Siddiqui, "Characteristics of some biomass briquettes prepared under modest die pressures," Biomass and Bioenergy, vol. 18, no. 3, pp. 223-228, 2000.

[25] J. T. Oladeji, C. C. Enweremadu, and E. O. Olafimihan, "Conversion of agricultural wastes into biomass briquettes," International Journal of Applied Agricultural and Apiculture Research, vol. 5, no. 2, pp. 116-123, 2009.

[26] M. J. O'Dogherty, "A review of the mechanical behaviour of straw when compressed to high densities," Journal of Agricultural Engineering Research, vol. 44, no. C, pp. 241-265, 1989.
[27] Deutsches Institut für Normunge, "Testing on solid fuels compresses untreated wood-requirements and testing," V. DIN, 51731, 1996.

[28] J. P. Singh, T. C. Thakur, S. Sharma, and R. K. Srivastava, "Effect of manner of stacking on changes in nutritional value of treated baled paddy straw by dripping technique," Agricultural Mechanization in Asia, Africa and Latin America, vol. 42, no. 4, pp. 84-87, 2011.

[29] C. O. Adegoke, "Preliminary investigation of sawdust as high grade solid fuel," Journal of Renewal Energy, vol. 1-2, pp. 102$107,1999$. 

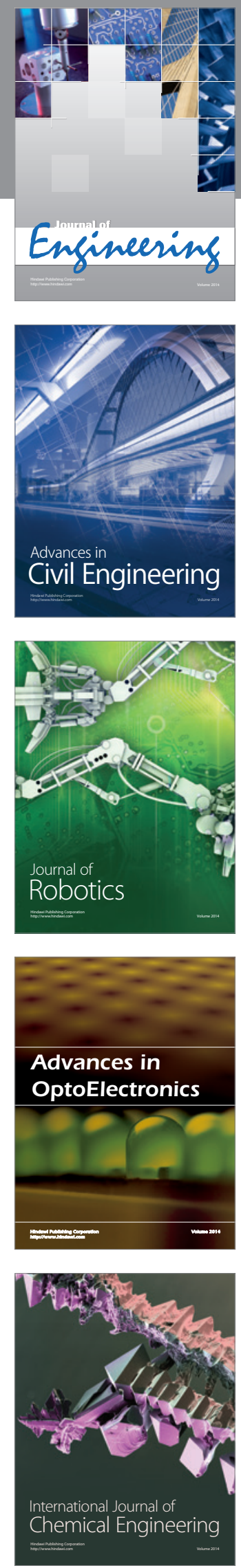

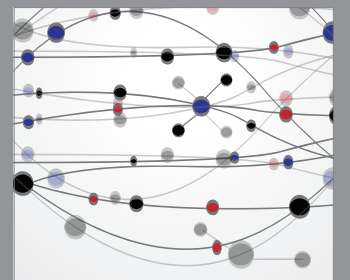

The Scientific World Journal
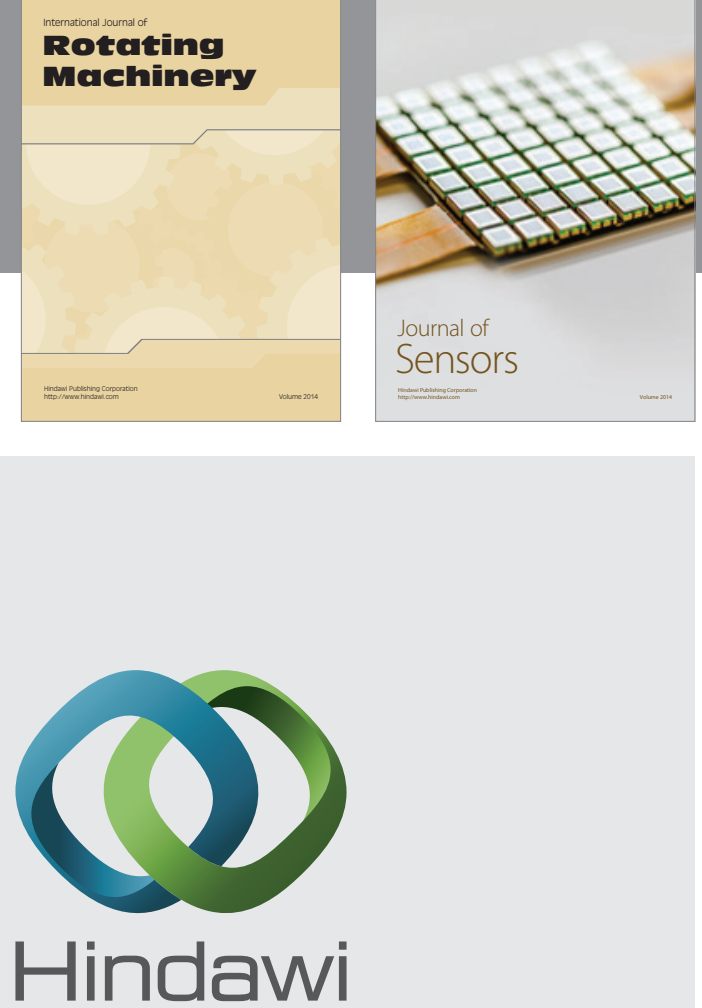

Submit your manuscripts at http://www.hindawi.com
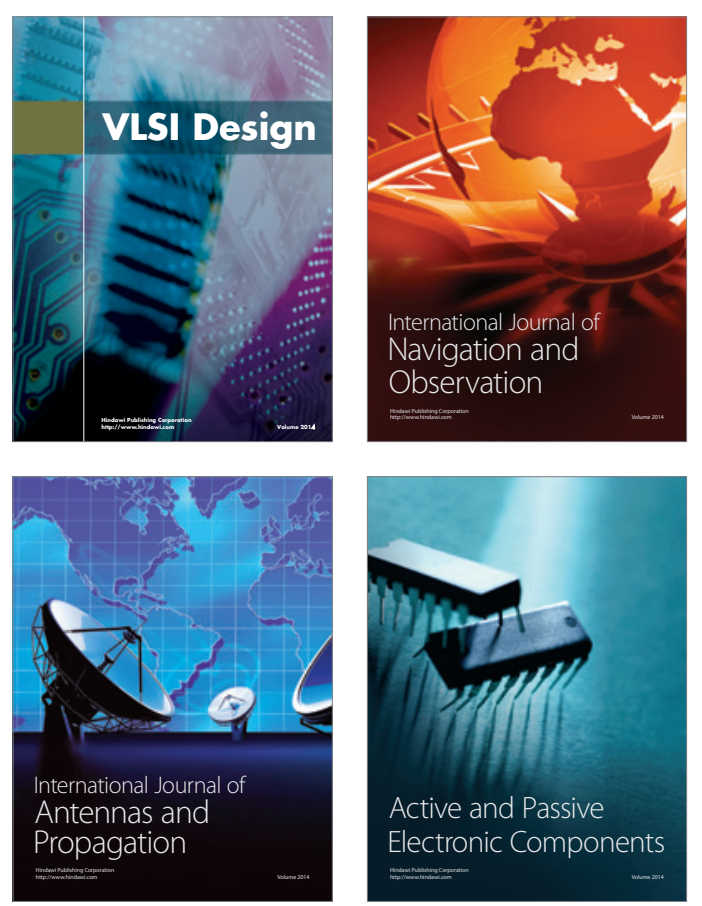
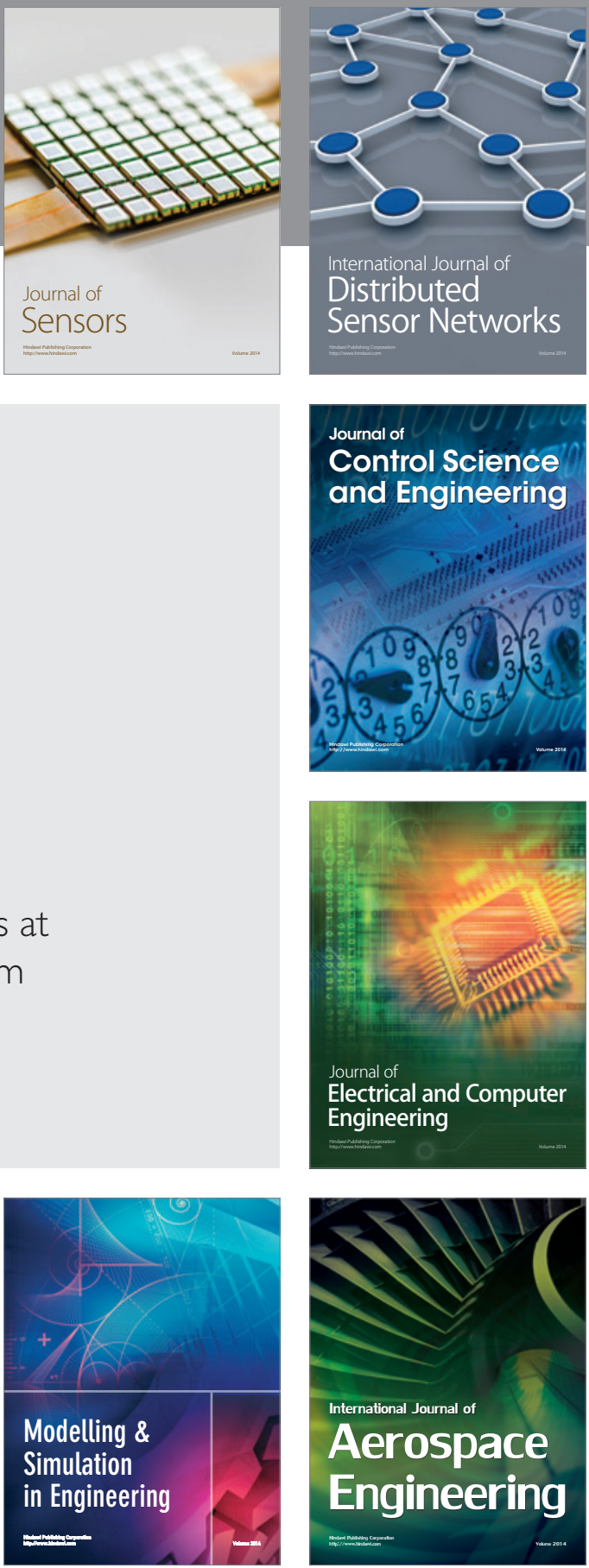

Journal of

Control Science

and Engineering
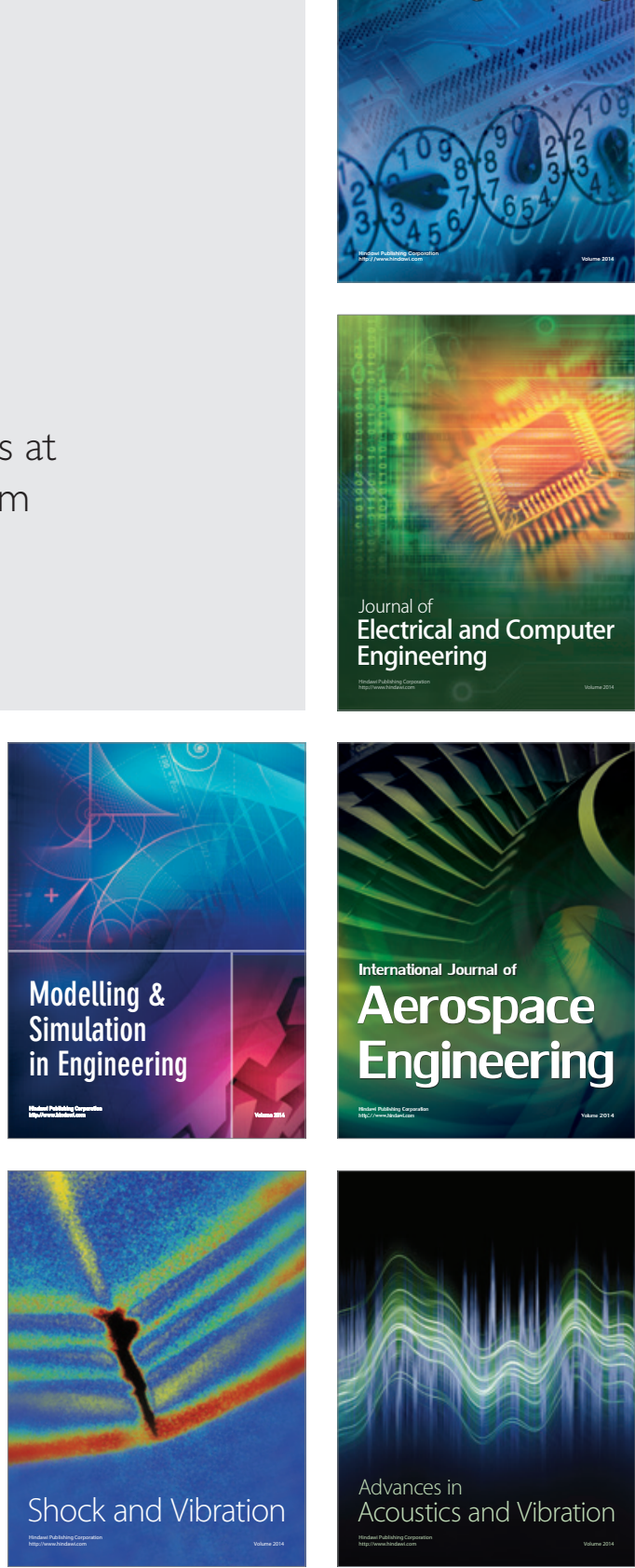